\title{
CRIMEN ABORTIONIS W RZYMSKIM PRAWIE KARNYM
}

Zagadnienie prawnej ochrony życia dziecka poczętego - współcześnie żywo dyskutowane zarówno w nauce prawa, jak i w dyskursie publicznym w ogóle - nie było przedmiotem szczególnego zainteresowania ze strony rzymskich jurystów ${ }^{1}$. Skupiali się oni na problematyce ochrony interesów majątkowych dziecka in utero oraz kwestiach związanych z jego przyszłą pozycją prawną (status), jaką nabywał z chwilą narodzenia². Do samej aborcji odnosili się jedynie marginalnie i w zupełnie innym kontekście, niż czyni się to współcześnie. Paradoksalnie jednak, może to uczynić rozważania nad aborcją w rzymskim prawie karnym szczególnie ciekawymi, również dla tych czytelników, którzy na co dzień nie zajmują się prawami antycznymi. W związku z tym autor zdecydował się na zastosowanie niektórych zwrotów znanych ze współczesnego języka prawniczego ${ }^{3}$.

\footnotetext{
* Mgr, Uniwersytet Marii Curie-Skłodowskiej w Lublinie; e-mail: bartosz.zalewski@ poczta.umcs.lublin.pl.

1 Materiały źródłowe zebrane są w: Iustiniani Digesta, [w:] P. Krueger, T. Mommsen (red.), Corpus Iuris Civilis, t. 1, Berolini 1893 (dalej: D.) 47, 11, 4; D. 48, 8, 8; D. 48, 19, 38, 5; D. 48, 19, 39 oraz Pauli Sententiae, [w:] G. Baviera (red.), Fontes Iuris Romani Anteiustiniani, t. 2, Firenze 1968 (dalej: P.S.) 5, 23, 14.

2 Choć i w tym względzie podstawa źródłowa nie należy do szczególnie obszernych, zob. P. Niczyporuk, Prywatnoprawna ochrona dziecka poczętego w prawie rzymskim, Białystok 2009, s. 20.

3 Nie jest to zabieg nowy, zob. K. Amielańczyk, Crimina legitima w rzymskim prawie publicznym, Lublin 2013. Autor posługuje się tu określeniami takimi jak: „znamiona strony podmiotowej" (tamże, s. 123-124), "formy stadialne i zjawiskowe przestępstwa" (tamże, s. 147 i nast.), "typizacja” (tamże, s. 159, 221), "przedmiot przestępstwa" (tamże, s. 251).
} 
Celem artykułu jest przedstawienie jak kształtował się proces penalizacji aborcji w prawie rzymskim ${ }^{4}$.

Przed przejściem do właściwego wywodu, należy poczynić kilka wyjaśnień terminologicznych. Tytułowe sformułowanie crimen abortionis nieznane było zachowanym rzymskim źródłom jurydycznym, które na określenie aborcji jako przestępstwa, posługiwały się zwrotami opisowymi, takimi jak abortionis poculum dare $e^{5}$ lub zawierającymi czasownik abigere (partum abigere) ${ }^{6}$. Średniowieczni glosatorzy dość konsekwentnie używali prostego sformułowania abortum facere ${ }^{7}$. Termin crimen abortionis pojawia się natomiast dopiero w źródłach prawniczych pochodzących

4 Wskazać należy, że omawiana problematyka była już przedmiotem dociekań naukowych. Na ich czoło wysuwa się obszerna monografia, której autorem był E. Nardi, zob. tenże, Procurato aborto in mondo greco-romano, Milano 1971. Z innych opracowań, zob. w szczególności: F.J. Dölger, Das Lebensrecht des ungeborenen Kindes und die Fruchtabtreibung in der Bewertung der heidnischen und christlichen Antike, "Antike und Christentum" 1934, t. 4, s. 1 i nast.; B. Łapicki, Wtadza ojcowska w starożytnym Rzymie. Okres klasyczny, seria: Bibliotheca Universitatis Liberae Polonae, nr 5 (28), Warszawa 1937, s. 19 i nast.; W.J. Watts, Ovid, the Law and Roman Society on Abortion, "Acta Classica" 1973, t. 16, nr 1, s. 89 i nast.; E. Eyben, Family Planning in Graeco-Roman Antiquity, ",Ancient Society" 1980/1981, t. 11/12, s. 5 i nast.; R. Mentxaka, El aborto en el derecho romano. Consideraciones sobre las fuentes juridicas clásicas, „Estudios de Deusto” 1983, t. 31, nr 61, s. 307 i nast.; Ch. Bernard, E. Deleury, F. Dion, P. Gaudette, Le statut de l'embryon humain dans l'Antiquité gréco-romaine, "Laval Théologique et Philosophique" 1989, t. 45, nr 2, s. 179 i nast.; S. Longosz, Prawo rzymskie wobec aborcji, [w:] H. Kowalski, M. Kuryłowicz (red.), Contra leges et bonos mores. Przestępstwa obyczajowe w starożytnej Grecji i Rzymie, Lublin 2005, s. 209 i nast.; G. Redl, Die fahrlässige Tötung durch Verabreichung schädigender Substanzen im römischen Strafrecht der Prinzipatszeit, „Revue Internationale des Droits de l'Antiquité” 2006, t. 52, s. 309 i nast.; K. Amielańczyk, Rzymianie $i$ ich "prawo medyczne" (aspekty prawno-karne), "Zeszyty Prawnicze" 2011, t. 11, z. 1, s. 69 i nast.; M.V. Sanna, Spes nascendi - spes patris, "Annali del Seminario Giuridico dell’Università degli Studi di Palermo" 2012, t. 55, s. 521 i nast.; M. Jońca, Aborcja w prawie Rzymu i wczesnego średniowiecza, „Edukacja Prawnicza” 2012, nr 10 (136), s. 46 i nast. Odnośnie do aborcji w prawie attyckim, zob. J. Rominkiewicz, Czy w prawie ateńskim istniat zakaz aborcji, „Acta Universitatis Wratislaviensis” Prawo 2012, nr 314, s. 17 i nast.

5 P.S. 5, 23, 14 (= D. $48,19,38,5)$.

6 D. 47, 11, 4; D. 48, 8, 8; D. 48, 19, 39. Zob. również: A. Berger, Partus abactus, [w:] A. Berger, Encyclopedic Dictionary of Roman Law, Philadelphia 1953, s. 619; A. Sevilla Conde, Morir ante suum diem. La infancia en Roma a través de la muerte, [w:] D. Justel Vicente (red.), Niños en la Antigüedad. Estudios sobre la infancia en el Mediterráneo antiguo, Zaragoza 2012, s. 202.

7 Zob. Accursius, Digestum Novum seu Pandectarum Iuris Civilis, t. 3, Lugduni 1627, glosa (dalej: gl.) Si mulierem ad D. 48, 8, 8; gl. Abigeret ad D. 48, 8, 8; gl. Constiterit ad D. 48, 8, 8; gl. Cicero ad. D. 48, 19, 39. 
z XVI-XVIII w. ${ }^{8}$ Podobnie jednak nieznane było rzymskim jurystom, powszechnie dziś stosowane (zarówno w literaturze romanistycznej, jak i współczesnych pracach dogmatycznych, a nawet w orzecznictwie), określenie nasciturus ${ }^{9}$, którego pierwotnie używano $\mathrm{w}$ piśmiennictwie wczesnochrześcijańskim na określenie mającego się narodzić Chrystusa ${ }^{10}$.

Jak podkreśla M. Jońca, pisarze pogańscy okazjonalnie poddawali aborcję krytyce ${ }^{11}$. Szczególnie widoczne jest to $\mathrm{w}$ pismach Owidiusza (Publius Ovidius Naso, 43 r. przed Chr.-ok. 18 r. po Chr.) ${ }^{12}$, który nie zawahał się określić aborcji jako zbrodni (crimen), wskazując, że prowadzi ona do śmierci dziecka poczętego (instituit teneros convellere fetus - "powoduje rozerwanie delikatnego płodu") i niesie ryzyko dla zdrowia jego matki ${ }^{13}$. Poeta podkreślał również, że gdyby w czasach dawniejszych również praktykowano aborcję, mogłoby to doprowadzić do wyginięcia rodzaju ludzkiego (gens hominum vitio deperitura fuit) ${ }^{14}$. Żyjący na przełomie I i II w. Juwenalis (Decimus Iunius Iuvenalis, ok. 60-130 r.) wprost stwierdził, że niektóre środki medyczne skutkują zabiciem człowieka w łonie matki (homines in ventre necandos) ${ }^{15}$.

8 Zob. P. Plaza y Moraza, Epitomes delictorum, causarumque criminalium, ex iure ponticio, regio, et caesareo, t. 1, Lugduni 1560, s. 444; J. Gronovius, Dissertatio juridica inauguralis ad quatuor fragmenta, quae ex Aelii Marciani primo Regularum libro in Pandectis supersunt, [w:] D. Fellenberg (red.), Jurisprudentia antiqua continens opuscula et dissertationes quibus leges antiquae praesertim Mosaicae, Graecae et Romanae illustrantur, t. 2, Bernae 1761, s. 651; P. Tollozan, Dissertatio philologico-iuridica inauguralis de maleficis et mathematicis et caeteris similibus, [w:] G. Oelrichs (red.), Theasuri dissertationum iuridicarum selectissimarum in Academiis Belgicis habitarum, vol. I, t. 3, Bremae-Lipsiae 1768, s. 231; J.B. Marencus, Joannes Bartholomæus Marencus j.u.d. civis Braydensis ut in amplissimum j.c. collegium cooptetur in regio Taurinensi athenaeo, Taurini 1787 , s. 44.

9 Zob. P. Niczyporuk, Prywatnoprawna ochrona..., s. 29 i nast. wraz z przytoczoną przez autora literaturą.

10 Zob. Ł. Pikuła, Nasciturus, [w:] A. Dębiński, M. Jońca (red.), Leksykon tradycji rzymskiego prawa prywatnego. Podstawowe pojęcia, Warszawa 2016, s. 244.

11 Zob. M. Jońca, Parricidium w prawie rzymskim, Lublin 2008, s. 28-29.

12 Poglądy Owidiusza na aborcję szczegółowo omawia W.J. Watts, Ovid, the Law..., s. 89 i nast.

13 Publius Ovidius Naso, Amores, [w:] L. Mueller (red.), P. Ovidii Asonis Carmina Amatoria, Berolini 1861 (dalej: Ovid., Am.) 2, 14. Odnośnie do aborcji, jako zagrożenia dla zdrowia kobiety ciężarnej, zob Ovid., Am. 2, 13.

14 Ovid., Am. 2, 14.

15 Decimus Iunius Iuvenalis, Satirae cum commentariis, C.F. Heinrich (red.), Bonnae 1839 (dalej: Iuv.) 6, 596. Za przesadne należy uznać jednak stwierdzenie B. Łapickiego, że 
Pilniejszej uwagi wymaga inne źródło literackie odnoszące się do pozbawienia życia dziecka poczętego - fragment mowy Pro Cluentio Cycerona (Marcus Tullius Cicero, 106-43 r. przed Chr.) ${ }^{16}$ :

Memoria teneo Milesiam quandam mulierem, cum essem in Asia, quod ab heredibus [secundis] accepta pecunia partum sibi ipsa medicamentis abegisset, rei capitalis esse damnatam; nec iniuria, quae spem parentis, memoriam nominis, subsidium generis, heredem familiae, designatum rei pulicae civem sustulisset ${ }^{17}$.

Słynny orator wspomina pewną kobietę, mieszkankę Miletu, która po śmierci swego męża przyjęła pieniądze od jego krewnych, w zamian za co uśmierciła swoje poczęte, a nienarodzone jeszcze dziecko, zażywając środki poronne. Miało to oczywiście służyć zachowaniu przez krewnych, wręczających kobiecie pieniądze, prawa do dziedziczenia po zmarłym. Arpinata podkreśla, że kobietę spotkała słuszna kara, bowiem zniweczyła nadzieję ojca, pamięć jego imienia, podporę (subsidium oparcie) rodu i spadkobiercę rodziny, a także przeznaczonego państwu obywatela ${ }^{18}$.

Jarosław Rominkiewicz wskazuje, że wydarzenia, o których wspomina Cyceron, miały miejsce najprawdopodobniej w 79 r. przed Chr., kiedy to przebywał on w Azji Mniejszej ${ }^{19}$. Autor ten słusznie zauważa, że nie wiadomo, na podstawie jakiego prawa (rzymskiego czy lokalnego ${ }^{20}$ ) skazano kobietę na śmierć, jednakże zakłada, że gdyby wyrok wydano $\mathrm{w}$ oparciu o prawo rzymskie, to zarzucanym czynem z pewnością nie była aborcja - tę bowiem uznawano za przestępstwo dopiero od III w.

Juwenalis uważał aborcję za homicidium, zob. B. Łapicki, Władza ojcowska..., s. 21. Jak podkreśla K. Amielańczyk, Rzymianie nie stworzyli uniwersalnego prawa skierowanego przeciwko zabójstwom, zob. K. Amielańczyk, Crimina legitima..., s. 160. Ciężko zatem uznać, że samo stwierdzenie o spowodowaniu śmierci dziecka poczętego można interpretować jako sugestię o penalizacji tego czynu.

16 Fragment ten przytacza również Tryfoninus w D. 48, 19, 39. Na temat samej sprawy Kluencjusza, zob. K. Amielańczyk, Lex Cornelia de sicariis et veneficis. Ustawa Korneliusza Sulli przeciwko nożownikom i trucicielom. 81 r. p.n.e., Lublin 2011, s. 84 i nast.

17 Marcus Tullius Cicero, Pro A. Cluentio oratio, [w:] W.Y. Fausset (red.), M. Tulli Ciceronis pro A. Cluentio oratio with explanatory and critical notes, London 1887 (dalej: Cic., Pro Cluentio) 11, 32.

18 Zob. R. Mentxaka, El aborto..., s. 310.

19 Zob. J. Rominkiewicz, Czy w prawie ateńskim..., s. 27.

20 Odnośnie do relacji między prawem rzymskim a prawami lokalnymi, zob. M. Kuryłowicz, Prawo rzymskie. Historia, tradycja, wspótczesność, Lublin 2003, s. 44-46. 
po Chr. ${ }^{21}$ Niemniej jednak, słowa Arpinaty jasno wskazują, że traktował on aborcję jako czyn moralnie naganny, godzien potępienia. Co więcej, logicznym wydaje się wniosek, że Cyceron liczył, że opinię jego podzielą sędziowie ${ }^{22}$.

Jednak pomimo tych - niekiedy bardzo kategorycznych - wypowiedzi niektórych autorów pogańskich, stwierdzić trzeba, że aborcję inkryminowano dopiero od czasów dynastii Sewerów (193-235 r. po Chr.) $)^{23}$. Żadne wcześniejsze źródła jurydyczne nie poświadczają, by była ona uznawana za przestępstwo, jakkolwiek wspomnieć warto, że nie oznacza to, iż w ogóle nie interesowała prawodawcy. Zgodnie bowiem z przekazem Plutarcha (zm. ok. 125 r. po Chr.) już Romulus postanowił, by użycie przez kobietę trucizny przeciw dzieciom upoważniało męża do rozwodu ${ }^{24}$. Możliwe było

${ }^{21}$ Zob. J. Rominkiewicz, Czy w prawie ateńskim..., s. 27. Emiel Eyben wydaje się sugerować, że podstawą dla orzeczenia kary śmierci względem kobiety był fakt przyjęcia pieniędzy od krewnych męża, zob. tenże, Family Planning..., s. 22. Teza ta nie znajduje jednak żadnego potwierdzenia w cytowanym źródle. Poza tym nie jest jasne, dlaczego inkryminacja aborcji na gruncie lokalnego prawa Miletu jest mniej prawdopodobna niż skazanie na śmierć kobiety za przyczynienie się do odmiennego ukształtowania sytuacji prawnomajątkowej potencjalnego kręgu spadkobierców, zwłaszcza, że Cyceron wyraźnie wskazuje, że kara była wymierzona za spowodowanie śmierci dziecka poczętego, zaś sam tok wywodu oratora oscyluje wokół trucicielstwa, nie zaś łapówkarstwa (ten kontekst podkreśla również R. Mentxaka, El aborto..., s. 309). W literaturze sugeruje się również, że chodziło o naruszenie praw ojca, zob. R. Crahay, Les moralistes anciens et l'avortement, „L'Antiquité Classique” 1941, t. 10, z. 1, s. 11. Teza ta byłaby godna rozważenia, gdyby nie fakt, że ojciec wówczas już nie żył, na co słusznie zwraca uwagę B. Łapicki, który jednak bezpodstawnie wyciąga z tego wnioski odnośnie do prawa rzymskiego, zob. tenże, Władza ojcowska..., s. 20.

22 Gertraud Redl wskazuje, że aborcję uznawano za naganną moralnie już w okresie poprzedzającym jej penalizację, zob. taż, Die fahrlässige..., s. 321.

23 Zob. W.J. Watts, Ovid, the Law..., s. 91; Ch. Bernard, E. Deleury, F. Dion, P. Gaudette, Le statut..., s. 187; W. Litewski, Abortio, [w:] W. Litewski, Stownik encyklopedyczny prawa rzymskiego, Kraków 1998, s. 3.

24 Zob. Plutarch, Romulus, [w:] K. Zeigler (red.), Plutarchi Vitae Parallelae, t. 1, fasc. 1, Leipzig 1957 (dalej: Plut., Romulus) 22. Według przekładu A. Tarwackiej: „(Romulus) wydal także prawa, z których jedno bardzo surowe nie zezwala żonie opuścić męża, pozwala natomiast na jednostronny rozwód z kobietą z powodu spędzenia płodu czy też podmienienia kluczy lub cudzołóstwa; gdyby ktoś ją odesłał bez powodu, (prawo) nakazuje, aby cały jego majątek otrzymała żona, on sam zaś został poświęcony Demeter; ten zaś, kto sprzedaje żonę (ma być) złożony w ofierze bóstwom podziemnym”, A. Tarwacka, „Leges regiae”, „Zeszyty Prawnicze” 2004, t. 4, z. 1, s. 239. Warto nadmienić, że Romulus miał również zakazać zabijania dzieci w wieku do lat trzech, zob. M. Jońca, Parricidium..., s. 187188. Szerzej na temat samych leges regiae, zob. B. Łapicki, Ustawy królewskie w starożytnym 
nawet skazanie żony na śmierć przez sąd domowy (iudicium domesticum) ${ }^{25}$, w ramach którego orzekał mąż wraz z najbliższymi krewnymi i sąsiadami lub przyjaciółmi ${ }^{26}$. W literaturze przedmiotu uważa się na ogół, że zawarta w legendarnej ustawie pierwszego rzymskiego króla okoliczność w istocie oznaczała dokonanie aborcji bez zgody mężczyzny ${ }^{27}$. W takiej sytuacji nie

Rzymie. Zagadnienie ich autentyczności, „Pamiętnik Historyczno-Prawny” 1933, t. 12, z. 6, s. 303-332 (wydano w formie odrębnej broszury); A. Watson, Roman Private Law and the Leges Regiae, "Journal of Roman Studies" 1972, t. 62, s. 100-105; B. Santalucia, Osservazioni sulla repressione criminale romana in età regia, [w:] M. Torelli i in. (red.), Le délit religieux dans la cité antique. Actes de la table ronde de Rome (6-7 avril 1978), Rome 1981, s. 39-49; R. Pankiewicz, Tzw. leges regiae a problematyka rodziny rzymskiej w epoce archaicznej, [w:] J. Jundziłł (red.), Rodzina w społeczeństwach antycznych $i$ wczesnym chrześcijaństwie. Literatura, prawo, epigrafika, sztuka, Bydgoszcz 1995, s. 59-84; Z. Bujuklić, Leges regiae: pro et contra, „Revue Internationale des Droits de l'Antiquité" 1998, nr 45, s. 89-142; G. Franciosi, Leges regiae, Napoli 2003; R. Laurendi, Leges regiae. "Ioui sacer esto» nelle leges Numae: nuova esegesi di Festo s.v. Aliuta, [w:] G. Purpura (red.), Revisione ed integrazione dei Fontes Iuris Romani Anteiustiniani (FIRA). Studi preparatori, t. 1. Leges, Torino 2012, s. 13-39.

${ }^{25}$ Wynikało to zapewne $\mathrm{z}$ faktu, że aborcję traktowano jako przypadek trucicielstwa, które początkowo karano wyłącznie po postępowaniu przed sądem domowym. Z czasem postępowanie przed iudicium domesticum toczyło się niezależnie od postępowania publicznego, zob. R. Pankiewicz, Tzw. leges regiae..., s. 71; W. Mossakowski, Iudicium domesticum w okresie republiki rzymskiej, [w:] J. Jundziłł (red.), Rodzina w społeczeństwach antycznych..., s. 88.

26 Zob. W. Litewski, Rzymski proces karny, Kraków 2003, s. 11. Instytucja iudicium domesticum budzi liczne kontrowersje w literaturze przedmiotu, zob. E. Volterra, Il preteso tribunale domestico in diritto romano, "Rivista Italiana per le Scienze Giuridiche” 1948, t. 2, z. 1/4, s. 104-153; W. Kunkel, Das Konsilium im Hausgericht, "Zeitschrift der Savigny-Stiftung für Rechtsgeschichte. Romanistische Abteilung" 1966, t. 83, s. 219-251; A. Balducci, Intorno al iudicium domesticum, "Archivio Giuridico” 1976, t. 191, nr 1/2, s. 69-97; A. Ruggiero, Nuove riflessioni in tema di tribunale domestico, [w:] V. Giuffrè (red.), Sodalitas. Scritti in onore di Antonio Guarino, t. 4, Napoli 1984, s. 1593-1600; W. Mossakowski, Iudicium domesticum..., s. 85-95; A. Ramon, Repressione domestica e persecuzione cittadina degli illeciti commessi da donne e "filii familias", [w:] L. Garofalo (red.), Il giudice privato nel processo civile romano. Omaggio ad Alberto Burdese, t. 3, Padova 2015, s. 617-678.

27 Zob. R. Crahay, Les moralistes anciens..., s. 12; S. Longosz, Prawo rzymskie..., s. 216; D. Ciuła, Najstarsze przyczyny rozwodu w prawie rzymskim, [w:] A. Dębiński, M. Wójcik (red.), Wokót problematyki matżeństwa w prawie rzymskim. Henrico Insadowski (1888-1946) in memoriam, Lublin 2007, s. 57-62; K. Amielańczyk, Rzymianie i ich prawo medyczne..., s. 86; M.V. Sanna, Spes nascendi..., s. 532-534; J. Zabłocki, Si mulier vinum bibit condemnatur, „Prawo Kanoniczne” 1989, t. 32, nr 1/2, s. 226, przyp. 16. Przeciwko takiej interpretacji oponował E. Eyben, zob. tenże, Family Planning..., s. 26. Natomiast H.F. Jolowicz wskazał, że chodziło o uprawianie przez żonę magii, zob. tenże, Historical Introduction to the Study of Roman Law, Cambridge 1952, s. 117. 
miałby on żadnych obowiązków finansowych względem żony, której należałaby się część mężowskiego majątku w przypadku jej porzucenia z przyczyn innych, niż określone przez ustawę ${ }^{28}$.

Natomiast pierwsze określenie aborcji jako przestępstwa, pochodzi dopiero z reskryptu cesarzy Septymiusza Sewera (Lucius Septimius Severus, zm. 211 r.) i Karakalli (Marcus Aurelius Severus Antoninus, zm. 217 r.), który wydany został około 211 r. ${ }^{29}$ Dosłowna treść reskryptu nie zachowała się do dnia dzisiejszego, należy ją zatem rekonstruować w oparciu o źródła pośrednie:

Marcianus libro primo regularum: Divus Severus et Antoninus rescripserunt eam, quae data opera abegit, a praeside in temporale exilium dandam: indignum enim videri potest impune eam maritum liberis fraudasse $e^{30}$.

Jak wskazuje Marcjanus (Aelius Marcianus, III w.), cesarze Sewer i Antoninus (Karakalla) w jednym ze swoich reskryptów postanowili, że kobieta dopuszczająca się aborcji, powinna być skazana przez namiestnika prowincji na tymczasowe wygnanie (temporale exilium), bowiem nie może zostać bezkarne oszukańcze pozbawienie (fraudare) męża potomstwa. Wydanie reskryptu związane było z zapytaniem skierowanym do cesarzy, a zatem powstał on na kanwie jakiejś konkretnej sprawy ${ }^{31}$. Jest to zresztą widoczne w jego treści, dotyczy bowiem dość specyficznego stanu faktycznego - kobiety uśmiercającej dziecko poczęte, ale jedynie wbrew woli byłego męża ${ }^{32}$.

Na okoliczności faktyczne leżące u podstaw cesarskiego rozstrzygnięcia nieco więcej światła rzucić może przekaz autorstwa Tryfoninusa (Claudius Tryphoninus, III w.):

28 Zob. Plut., Romulus 22. Zob. również M. Morin, Les confins du droit civil et $d u$ droit pénal: l'avortement et les droits de l'enfant conçu, „McGill Law Journal” 1997, t. 42, nr 2, s. 212.

29 Zob. S. Longosz, Prawo rzymskie..., s. 218; M.V. Sanna, Spes nascendi..., s. 530.

30 D. 47, 11, 4.

31 Na temat roli reskryptów w polityce karnej prowadzonej przez rzymskich cesarzy (w omawianym przez autora przypadku - cesarza Hadriana), zob. K. Amielańczyk, Rzymskie prawo karne w reskryptach cesarza Hadriana, Lublin 2006, s. 23 i nast.

32 Nadmienić warto, że prawo rzymskie przewidywało również specjalną procedurę (inspectio ventris) na wypadek sporu między kobietą, a jej byłym mężem, odnośnie do tego, czy kobieta jest brzemienna, zob. P. Niczyporuk, Stwierdzenie ciaży (inspectio ventris) jako środek ochrony interesów dziecka poczętego w prawie rzymskim, „Miscellanea Historico-Iuridica" 2010, t. 9, s. 29 i nast. 
Tryphoninus libro decimo disputationum: Cicero in oratione pro cluentio habito scripsit milesiam quandam mulierem, cum esset in asia, quod ab heredibus secundis accepta pecunia partum sibi medicamentis ipsa abegisset, rei capitalis esse damnatam. Sed et si qua visceribus suis post divortium, quod praegnas fuit, vim intulerit, ne iam inimico marito filium procrearet, ut temporali exilio coerceatur, ab optimis imperatoribus nostris rescriptum est ${ }^{33}$.

Cytowany fragment rozpoczyna wzmianka dotycząca przytaczanego już wspomnienia Cycerona, o którym mowa w Pro Cluentio. Dalej, jak gdyby w kontrze do rozstrzygnięcia mieszkańców Miletu ${ }^{34}$, jurysta wskazuje, że jeżeli kobieta dokonała aborcji, a nastąpiło to już po rozwodzie z mężem, powinna zostać skazana na tymczasowe wygnanie. Wyraźnie podkreśla się przy tym, że odpowiedzialność kobiety determinowana jest tym, że dokonując aborcji nie chce urodzić dziecka znienawidzonemu (inimicus) mężowi.

Po zestawieniu obydwu cytowanych fragmentów wyłania się zatem następujący stan faktyczny: małżeństwo ustało na skutek rozwodu, ale była żona pozostawała brzemienna. Chcąc uniknąć urodzenia dziecka swojego byłego małżonka, dokonała aborcji, a tym samym pozbawiła go potomka $^{35}$. Nie ma również najmniejszych wątpliwości, że sankcją, jaką przewidzieli cesarze $\mathrm{w}$ tej sytuacji, było tymczasowe wygnanie, co potwierdza także innych fragment zachowany w Digestach:

Ulpianus libro 33 ad edictum: Si mulierem visceribus suis vim intulisse, quo partum abigeret, constiterit, eam in exilium praeses provinciae exiget ${ }^{36}$.

Jak zauważył Ulpian (Gnaeus Domitius Annius Ulpianus, zm. 223 r.), jeżeli kobieta dokona aborcji, powinna zostać skazana na wygnanie. Fragment ten ma najbardziej ogólny charakter spośród wszystkich dotychczas przytoczonych. Nie wskazuje bowiem, że dokonanie aborcji powinno nastąpić wbrew woli lub bez wiedzy ojca dziecka poczętego, na temat któ-

33 D. $48,19,39$.

34 Podobną interpretacje proponuje M. Wibier, zob. tenże, Cicero's Reception in the Juristic Tradition of the Early Empire, [w:] P.J. du Plessis (red.), Cicero's Law: Rethinking Roman Law of the Late Republic, Edinburgh 2016, s. 108. Trzeba jednak zauważyć, że autorzy z XVI-XVIII w. traktowali fragment mowy Cycerona, jako argument przemawiający za karaniem aborcji, tak jak za homicidium, zob. P. Plaza y Moraza, Epitomes delictorum..., s. 444; J.B. Marencus, Joannes Bartholomæus..., s. 44.

35 Zob. R. Mentxaka, El aborto..., s. 310.

${ }^{36}$ D. $48,8,8$. 
rego Ulpian milczy. Jurysta wzmiankuje, że sankcją jaka grozi kobiecie jest wygnanie, choć jak można przypuszczać na podstawie innych cytowanych źródeł, nie jest zbyt precyzyjny i pomija tymczasowy charakter exilium. Uwzględniając różnice między przytaczanymi wcześniej fragmentami Marcjanusa i Tryfoninusa a cytowanym wyimkiem z pism Ulpiana, R. Mentxaka wyraziła pogląd, że tekst ten jest interpolowany przez kompilatorów justyniańskich, wprowadzających zmiany pod wpływem chrześcijaństwa $^{37}$. Autorka nie tłumaczy jednak, dlaczego nie zmodyfikowano w żaden sposób fragmentów pochodzących od dwu pozostałych jurystów. Tymczasem, jest to zagadnienie ważkie, bowiem jeżeli rzeczywiście w okresie justyniańskim chciano traktować aborcję jako homicidium, zmiana taka powinna być przeprowadzona konsekwentnie. Jakkolwiek zatem pogląd R. Mentxaki jest niezmiernie interesujący, to nie sposób jednoznacznie stwierdzić, czy autorka ma rację ${ }^{38}$.

Wszystkie zaprezentowane fragmenty Digestów dotyczą odpowiedzialności karnej kobiety ciężarnej, jaką ponosiła ona w związku z uśmierceniem swego nienarodzonego dziecka, czym naruszała prawa swego męża do posiadania potomstwa ${ }^{39}$. Niezależnie od tego, prawo rzymskie przewidywało odpowiedzialność osób trzecich, które podawały kobiecie środek poronny (poculum abortionis), co ciekawe, zestawiony z afrodyzjakiem (poculum amatorium $)^{40}$ :

37 Zob. R. Mentxaka, El aborto..., s. 315.

38 Dodać należy, że samo ustawodawstwo Justyniana względem aborcji jest dość niekonsekwentne, na co zwrócił uwagę S. Longosz, zob. tenże, Prawo rzymskie..., s. 219. Konstytucją z 533 r. (Codex Iustinianus, [w:] P. Krueger (red.), Corpus Iuris Civilis, t. 2, Berolini 1892, 5, 17, 11) cesarz przywrócił aborcję do przesłanek uzasadniających rozwód (nie była ona znana ustawodawstwu rozwodowemu Konstantyna Wielkiego i Teodozjusza II), by znieść ją w 542 r. (Novellae, [w:] R. Schoell (red.), Corpus Iuris Civilis, t. 3, Berolini 1895, 117, 8).

39 Żyjący w XVIII w. francuski znawca prawa karnego, P.F. Muyart de Vouglans, bazując na źródłach rzymskich, określił to przestępstwo, jako avortement volontaire i wyraźnie odróżnił od aborcji dokonanej przez osoby trzecie, zob. P.F. Muyart de Vouglans, Les loix criminelles de France, dans leur ordre naturel, t. 1, Paris 1781, s. 160.

40 Zob. G.F. Falchi, Diritto penale romano, Padova 1932, s. 157; K. Amielańczyk, Lex Cornelia..., s. 99-100. Trzeba jednak zauważyć, że w literaturze przedmiotu formułowany jest pogląd, że na podstawie tego przepisu odpowiedzialność karną ponosiły również osoby trzecie, które udzieliły kobiecie pomocy w dokonaniu aborcji, zob. R. Mentxaka, El aborto..., s. 313 wraz z przytoczoną przez autorkę literaturą. 
Paulus libro quinto sententiarum: Qui abortionis aut amatorium poculum dant, etsi dolo non faciant, tamen quia mali exempli res est, humiliores in metallum, honestiores in insulam amissa parte bonorum relegantur. Quod si eo mulier aut homo perierit, summo supplicio adficiuntur ${ }^{41}$.

Jak wskazuje Paulus (Iulius Paulus, III w.), osoba która podaje kobiecie brzemiennej środek poronny, nawet nie działając w złym zamiarze, podlega karze wygnania i konfiskacie części majątku jeżeli przynależy do klasy honestiores. Osoby niższego stanu (humiliores) zsyłano natomiast do pracy w kopalniach (opus metalli) ${ }^{42}$. Jeżeli skutkiem była śmierć kobiety, wówczas stosowano karę śmierci, a więc przestępstwo zaaplikowania kobiecie ciężarnej środka poronnego występowało również - wedle współczesnej terminologii - w typie kwalifikowanym poprzez następstwo. Paulus dokonuje zatem twórczej interpretacji lex Cornelia de sicariis et veneficis, traktując środek poronny w sposób zbliżony do trucizny (venenum malum) ${ }^{43}$, co $\mathrm{w}$ jakimś sensie koresponduje z wypowiedzią żyjącego współcześnie z jurystą, chrześcijańskiego apologety Tertuliana, który stwierdził, że zabicie dziecka poczętego stanowi homicidium ${ }^{44}$. Sprawcą czynu, o którym mowa we fragmencie Sentencji mógł być w zasadzie każdy poza matką dziecka, jednakże domyślać się można, że odpowiedzialność dotyczyła najczęściej akuszerek, lekarzy czy różnego rodzaju znachorów, których zapewne w antycznym Rzymie nie brakowało ${ }^{45}$.

Poczyniony przegląd zachowanych źródeł skłania do postawienia pytania, czy odpowiedzialność osób trzecich za podanie środka poronnego kobiecie brzemiennej jest ograniczona jedynie do sytuacji, gdy kobieta dokonuje aborcji wbrew woli męża (względnie byłego męża), czy być może zachodziła ona zupełnie niezależnie od ewentualnej odpowiedzialności kobiety? Z przytoczonego fragmentu Sentencji Paulusa w żaden sposób nie wynika, by zależność taka istniała, biorąc jednak pod uwagę samą bliskość czasową między wypowiedzią Paulusa, a reskryptem Septymiusza

41 D. 48, 19, 38; fragment zachowany również w P.S. 5, 23, 14.

42 Zob. E. Costa, Crimini e pene da Romolo a Giustiniano, Bologna 1921, s. 160-161; F. Salerno, "Ad metalla". Aspetti giuridici del lavoro in miniera, Napoli 2003, s. 77-78.

43 Zob. K. Amielańczyk, Lex Cornelia..., s. 99-100.

44 Zob. Tertulian, Apologeticum, C. Becker (red.), Munich 1962, 9, 8; zob. również: B. Łapicki, Wtadza ojcowska..., s. 21; M. Starowieyski, Aborcja i życie nienarodzonych w starożytności chrześcijańskiej, „Warszawskie Studia Teologiczne” 2009, t. 22, cz. 1, s. 130 i nast.

45 Zob. K. Amielańczyk, Rzymianie i ich "prawo medyczne”..., s. 88. 
Sewera i Karakalli (pierwsze ćwierćwiecze III w.) - nie można jej wykluczyć. Pomocna w próbie rozstrzygnięcia tego zagadnienia może być rekonstrukcja znamion obydwu czynów.

Jak przyjmuje się we współczesnej doktrynie prawa karnego, bezpośrednim przedmiotem ochrony przy przestępstwie aborcji jest życie dziecka poczętego ${ }^{46}$. Zaprezentowane fragmenty z pism Marcjanusa i Tryfoninusa literalnie wskazują, że stanowisko rzymskiego prawodawcy było zgoła odmienne - objął on bowiem ochroną prawo ojca do posiadania potomstwa ${ }^{47}$. Nie może być to specjalnym zaskoczeniem, biorąc pod uwagę, że prawo rzymskie - przynajmniej pierwotnie - dopuszczało w ogóle zabicie dzieci przez ojca w ramach ius vitae ac necis ${ }^{48}$. Co więcej, zdaniem

46 Jest to stanowisko dominujące w piśmiennictwie, zob. K. Wiak, Polskie prawo karne wobec dziecka poczętego, [w:] A. Dębiński, A. Grześkowiak, K. Wiak (red.), Ius et lex. Księga Jubileuszowa ku czci Profesora Adama Strzembosza, Lublin 2002, s. 103; K. Wiak, Komentarz do art. 152, [w:] A. Grześkowiak, K. Wiak (red.), Kodeks karny. Komentarz, Warszawa 2018, Legalis, nb. 4; J. Potulski, Dziecko poczęte jako pokrzywdzony w przestęstwie aborcyjnym. Postanowienie SN z dnia 26 marca 2009 r., I KZP 2/09, "Gdańskie Studia Prawnicze - Przegląd Orzecznictwa" 2009, nr 4, s. 137; M. Olszówka, Początek człowieka a początek życia ludzkiego w orzecznictwie Trybunału Konstytucyjnego i Sądu Najwyższego, [w:] L. Bosek, M. Królikowski (red.), Wspótczesne wyzwania bioetyczne, Warszawa 2010, s. 216-217; A. Księżopolska-Breś, Odpowiedzialność karna za dzieciobójstwo w prawie polskim, Warszawa 2010, s. 64; Ł. Czebotar, Z. Gądzik, Prawnokarna ochrona życia i zdrowia dziecka poczętego w ustawodawstwie polskim, „Kościół i Prawo” 2013, nr 2 (15), s. 262; M. Królikowski, Komentarz do art. 152, [w:] M. Królikowski, R. Zawłocki (red.), Kodeks karny. Część szczególna, t. 1. Komentarz do art. 117-221, Warszawa 2017, Legalis, nb. 1; P. Rafałowicz, Poczatek ochrony życia dziecka poczętego - analiza przedmiotu ochrony przestępstw aborcyjnych, „Pomeranian Journal of Life Sciences” 2016, t. 62, nr 3, s. 63-64; E. Plebanek, Życie i zdrowie dziecka poczętego jako przedmiot prawnokarnej ochrony (wybrane problemy wykładnicze w perspektywie najnowszych propozycji legislacyjnych), „Czasopismo Prawa Karnego i Nauk Penalnych” 2016, t. 20, z. 4, s. 7; M. Budyn-Kulik, Komentarz do art. 152, [w:] M. Mozgawa (red.), Kodeks karny. Komentarz aktualizowany, LEX 2017, uwaga 1.

47 Pogląd taki wyrazili przykładowo: Ch. Bernard, E. Deleury, F. Dion, P. Gaudette, Le statut..., s. 187-188; J. Rominkiewicz, Czy w prawie ateńskim..., s. 39; K. Amielańczyk, Rzymianie i ich "prawo medyczne” ..., s. 87-88. Zob. również: P. Ferretti, In rerum natura esse in rerum humanis nondum esse. L'identità del concepito nel pensiero giurisprudenziale classico, [Milano] 2008, s. 138 i nast., który konkludując swoje wywody stwierdza, że nie ma podstaw by wykluczyć, iż omawiane regulacje miały chronić życie poczęte, zob. tamże, s. 144.

48 Szerzej na temat iuris vitae ac necis, zob. P. Bonfante, Corso di diritto romano, t. 1. Diritto di famiglia, Roma 1925, s. 69 i nast.; M. Kaser, Der Inhalt der patria potestas, "Zeitschrift der Savigny-Stiftung für Rechtsgeschichte. Romanistische Abteilung" 1938, t. 58, s. 62 i nast.; tenże, Das römische Privatrecht, t. 2, München 1975, s. 202 i nast.; B. Albanese, Note 
przeważającej części badaczy ${ }^{49}$, dziecko poczęte traktowane było przez rzymskich jurystów jako mulieris portio vel viscerum, co w sposób kategoryczny stwierdził Ulpian ${ }^{50}$.

Wątpliwości odnośnie do prawidłowej interpretacji przekazu Ulpiana i jego miarodajności dla całego prawa rzymskiego wyraził W. Waldstein ${ }^{51}$, a w literaturze polskojęzycznej podzielił je P. Niczyporuk ${ }^{52}$. Pozostawiając niejako na marginesie uwagi o ochronie interesów majątkowych dziecka poczętego, należy zauważyć, że proste stwierdzenie, iż prawo rzymskie nie wyznaczało żadnego "standardu ochrony” życia dziecka poczętego jest zupełnym nieporozumieniem, o czym świadczy szereg przekazów źródłowych ${ }^{53}$. Dość wskazać, że według reskryptu cesarza Hadriana zwyczajowo nie wykonywano kary śmierci na kobiecie brzemiennej, do czasu aż ta nie doczekała rozwiązania:

Ulpianus libro 27 ad Sabinum: Imperator Hadrianus publicio Marcello rescripsit liberam, quae praegnas ultimo supplicio damnata est, liberum parere et solitum esse

sull'evoluzione storica del ius vitae ac necis, [w:] G.G. Archi (red.), Scritti in onore di Contardo Ferrini pubblicati in occasione della sua beatificazione, t. 3, Milano 1948, s. 343 i nast.; M. Jońca, Parricidium..., s. 178 i nast.; K. Amielańczyk, Zmierzch "ius vitae necisque" (z badań nad prawodawstwem karnym cesarza Hadriana), "Annales Universitatis Mariae Curie-Skłodowska” Sectio G Ius 2007/2008, t. 54/55, s. 7 i nast.

49 Przykładowo: B. Biondi, Il diritto romano cristiano, t. 2, Milano 1952, s. 339 (odnośnie do okresu klasycznego); R. Taubenschlag, Rzymskie prawo prywatne, Warszawa 1955, s. 107; W. Osuchowski, Zarys rzymskiego prawa prywatnego, Warszawa 1962, s. 201; A. Burdese, Manuale di diritto privato romano, Torino 1964, s. 158; M. Kaser, Das römische Privatrecht, t. 1, München 1971, s. 272; M. Jońca, Parricidium..., s. 29; S. Longosz, Prawo rzymskie..., s. 215.

50 Zob. D. 25, 4, 1, 1. Należy również zauważyć, że kwestia, czy płód ludzki jest istotą żywą była przedmiotem dyskusji w starożytności, o czym może świadczyć wydana przez żyjącego pod koniec II w. autora, zwanego Pseudo-Galenem, rozprawka zatytułowana Czy płód ludzki jest istota żywą?, zob. S. Longosz, Prawo rzymskie..., s. 213; J. Rominkiewicz, Czy w prawie ateńskim..., s. 27-29. Sama okoliczność roztrząsania tego zagadnienia wiele mówi o stanie wiedzy starożytnych odnośnie do dziecka poczętego i jego rozwoju. Na temat Pseudo-Galena, zob. C. Petit, What Does Pseudo-Galen Tell us That Galen Does Not? Ancient Medical Schools in the Roman Empire, [w:] P. Admason, R. Hansberger, J. Wilberding (red.), Philosophical Themes in Galen, London 2014, s. 269 i nast.

51 Zob. wydany w języku polskim artykuł W. Waldsteina, Problem interpretacji źródet a status dziecka w tonie kobiety (nasciturus), tłum. F. Wycisk, "Zeszyty Prawnicze” 2006, t. 6, z. 2, s. 7 i nast.

52 Zob. P. Niczyporuk, Prywatnoprawna ochrona..., s. 63.

53 D. 1, 5, 7; D. 1, 5, 18; D. 11, 8, 2. Zob. również A. Guarino, Diritto privato romano. Lezioni istituzionali di diritto romano, Napoli 1958, s. 156. 
servari eam, dum partum ederet. Sed si ei, quae ex iustis nuptiis concepit, aqua et igni interdictum est, civem Romanum parit et in potestate patris ${ }^{54}$.

Według M.G. Zoz interpretację cytowanego fragmentu determinuje okoliczność, że kobieta skazana na śmierć stawała się serva poenae, a zatem regulacja odnosi się do dzieci niewolniczych i u jej podstaw leży motywacja ekonomiczna ${ }^{55}$. Z poglądem tym jednak ciężko się zgodzić, bowiem zupełnie pomija on znaczenie favor libertatis ${ }^{56}$. Analizując przekazy jurystów wiążące się z reskryptem Hadriana ${ }^{57}$, P. Feretti wskazuje natomiast, że celem działania prawodawcy zakazującego wykonania „kary głównej” oraz torturowania kobiet brzemiennych było zabezpieczenie możliwości narodzin dziecka poczętego ${ }^{58}$. Pogląd ten podziela również M.V. Sanna ${ }^{59}$. Dodać należy, że z przytoczonego fragmentu pism Ulpiana, który relacjonuje treść reskryptu, wywnioskować można, że cesarz odnosił się do istniejącej już praktyki, którą aprobował.

Stanowisko M.V. Sanny odnosi się również do przekazu Marcellusa, który wypada $\mathrm{w}$ tym miejscu przytoczyć. Zgodnie $\mathrm{z}$ fragmentem pism tego jurysty, ustawy królewskie (leges regiae) zabraniały grzebania zmarłej kobiety ciężarnej przed wyjęciem z jej łona dziecka:

Marcellus libro 28 digestorum: Negat lex regia mulierem, quae praegnas mortua sit, humari, antequam partus ei excidatur: qui contra fecerit, spem animantis cum gravida peremisse videtur ${ }^{60}$.

Można zatem przyjąć, że Rzymianie intuicyjnie wyczuwali, że nowopowstałe życie jest odrębne od życia matki i wymaga ochrony, choć $\mathrm{w}$ istocie była ona realizowana na poziomie, który z dzisiejszego punktu widzenia określić należy jako bardzo niski. Sama okoliczność, że rzymscy juryści mieli różne zapatrywania odnośnie do statusu dziecka poczętego nie powinna być zaskoczeniem. Ulpian określał je wprawdzie jako „jesz-

54 D. $1,5,18$.

55 Zob. M.G. Zoz, Le costituzioni imperiali nella giurisprudenza. Fonti giuridiche e diritto delle persone, Trieste 2007, s. 10.

56 Na ten temat, zob. P. Niczyporuk, Prywatnoprawna ochrona..., s. 53-55; P. Voci, Istituzioni di diritto Romano, Milano 1954, s. 90-91.

57 Zob. D. 48, 19, 3; P.S. 1, 12, 4.

58 Zob. P. Feretti, In rerum natura..., s. 135.

59 Zob. M.V. Sanna, Spes nascendi..., s. 529-530.

${ }^{60}$ D. $11,8,2$. 
cze nie żyjącą istotę" (nondum animal) ${ }^{61}$, ale z drugiej strony ten sam jurysta wyraził przekonanie, że skoro zgodnie z reskryptem Hadriana nie można wykonać kary śmierci na kobiecie ciężarnej, to nie powinno się jej również torturować6 ${ }^{6}$. Wysnuć stąd można wniosek o braku konsekwencji w postrzeganiu problematyki ochrony dziecka poczętego przez rzymskich prawników ${ }^{63}$. Zasygnalizować oczywiście trzeba, że pomimo zapewnienia dziecku in utero wąskiego zakresu ochrony prawnej, nie ma wątpliwości, iż nie było ono wyposażone w zdolność prawną, którą jak wiadomo nabywało dopiero z momentem narodzin. Nie zmienia tego dopuszczalność zastosowania fikcji prawnej, która polegała wszak na przyjęciu, że dziecko narodziło się wcześniej niż w rzeczywistości, przed zdarzeniem warunkującym możliwość nabycia określonych praw podmiotowych ${ }^{64}$. $\mathrm{W}$ tak skromnym opracowaniu zagłębienie się w problematykę zdolności prawnej nie jest jednak możliwe ${ }^{65}$.

Rozważania dotyczące zakazu wykonywania kary śmierci na kobiecie brzemiennej oraz jej torturowania mogą być istotne dla analizy przedmiotu ochrony przy przestępstwie podawania kobiecie środków poronnych, o którym pisał Paulus. O ile bowiem odpowiedzialność karna kobiety brzemiennej dokonującej aborcji uzasadniona była naruszeniem praw

61 D. $38,8,1,8$.

62 Zob. D. 48, 19, 3.

63 Zob. E. Volterra, Istituzioni di diritto privato romano, Roma 1961, s. 47-48.

64 Zob. B. Kuebler, E. Seckel (red.), Gai Institutionum Commentarii Quattuor, Lipsiae 1903, 1, 147; D. 1, 5, 7; D. 50, 16, 231.

65 Warto zauważyć, że problematyka zdolności prawnej dziecka poczętego (a w istocie jej braku) została uznana przez polski Trybunał Konstytucyjny za indyferentna przy ocenie braku konstytucyjności tzw. „przesłanki społecznej” umożliwiającej dokonanie aborcji (art. 4a ust. 1 pkt 4 ustawy z dnia 7 stycznia 1993 r. o planowaniu rodziny, ochronie płodu ludzkiego i warunkach dopuszczalności przerywania ciąży, Dz. U. z 1993 r. Nr 17, poz. 78 z późn. zm.). W orzeczeniu z dnia 28 maja 1997 r., sygn. akt K 26/96 (OTK 1997/2/19) Trybunał stwierdził: „Zdolność prawna, o której mówią przepisy kodeksu cywilnego, ma charakter czysto funkcjonalny i odnosi się wyłącznie do instytucji prawa cywilnego. W szczególności nie można utożsamiać zdolności prawnej określonej w art. 8 k.c. $\mathrm{z}$ podmiotowością prawną w całym systemie prawa. Podmiotowość prawna przynależna jest każdemu człowiekowi". Ciężko jednak przełożyć rozważania Trybunału na grunt prawa rzymskiego, bowiem zarówno pojęcie podmiotu prawa, jak i zdolności prawnej powstały dopiero w epoce nowożytnej (XVIII-XIX w.), zob. M. Jońca, Subiectum iuris, [w:] A. Dębiński, M. Jońca (red.), Leksykon tradycji rzymskiego prawa prywatnego. Podstawowe pojęcia, Warszawa 2016, s. 354-355; T. Giaro [w:] W. Dajczak, T. Giaro, F. Longchamps de Bérier, Prawo rzymskie. U podstaw prawa prywatnego, Warszawa 2011, s. 176 i nast. 
ojca, które zostałyby zniweczone wraz z uśmierceniem dziecka poczętego $^{66}$, o tyle uzasadnieniem dla penalizacji aplikowania kobiecie poculi abortionis było spowodowanie śmierci nienarodzonego oraz potencjalne zagrożenie dla życia jego matki ${ }^{67}$. Brak jest podstaw źródłowych, by przyjmować analogiczne ograniczenie, jak w przypadku odpowiedzialności kobiety ciężarnej. Nadmienić trzeba, iż pozornie wydawać by się mogło, że pole do rozmaitych dalszych interpretacji otwiera również użycie przez jurystę zwrotu homo, który jednakże należy odnieść nie do śmierci abortowanego dziecka, a mężczyzny umierającego na skutek zażycia afrodyzja$\mathrm{ku}^{68}$. W odmiennym przypadku określenie odmiennych sankcji z uwagi na skutki przestępstwa staje się niezrozumiałe.

Przechodząc do problematyki określanej dziś jako znamiona strony przedmiotowej czynu, stwierdzić trzeba, że na podstawie reskryptu cesarskiego odpowiedzialność ponosiła kobieta, która zabiła dziecko poczęte, pochodzące z matrimonium legitimum. Wniosek taki jest racjonalny w świetle uzasadnienia cesarskiej konstytucji. Oznacza to, że dla stwierdzenia odpowiedzialności kobiety należałoby ustalić, czy dziecko zostało poczęte w okresie koncepcyjnym. Niekiedy mogło być to utrudnione, o ile nie zachowały się jego szczątki, które pozwoliłyby na przybliżone choćby stwierdzenie, w którym tygodniu ciąży dokonana została aborcja. Tego rodzaju praktycznymi trudnościami juryści rzymscy się jednakże nie zajęli.

Sama czynność sprawcza polegać mogła na wszelkich działaniach "zadających gwałt łonu” (visceribus vim intulisse) ${ }^{69}$. Najczęściej chodziło zapewne o zażycie środków poronnych, ale również poprzez uciskanie ciała, gwałtowne podskakiwanie, dźwiganie nadmiernych ciężarów czy nawet - jak wierzono - głośne ziewanie ${ }^{70}$. Znana była również aborcja w wyniku interwencji chirurgicznej ${ }^{71}$, choć należy przypuszczać, że ta wy-

${ }^{66}$ Domyślać się należy, że przede wszystkim chodziło o utratę potencjalnego spadkobiercy, zob. R. Mentxaka, El aborto..., s. 311.

67 Zob. K. Amielańczyk, Lex Cornelia..., s. 100. W podobnym duchu wypowiedział się B. Łapicki, który jednak rozciągnął powyższy wniosek również na odpowiedzialność matki dziecka penalizowaną reskryptem Septymiusza Sewera i Karakalli, zob. tenże, Wtadza ojcowska..., s. 21.

68 Zob. M.V. Sanna, Spes nascendi..., s. 540, przyp. 66.

69 D. $48,8,8$.

70 Zob. E. Eyben, Family Planning..., s. 11.

${ }^{71}$ Zob. tamże. 
magała udziału osób trzecich. Z punktu widzenia modelu przestępstwa zaproponowanego przez Klaudiusza Saturninusa (Claudius Saturninus, II w. $)^{72}$, stwierdzić można, że przestępstwo aborcji dokonywano per factum - poprzez działanie prowadzące do określonego skutku materialne$\mathrm{go}^{73}$, przez co należy rozumieć utratę życia przez dziecko poczęte, a tym samym utratę potomka przez aktualnego lub byłego męża sprawczyni.

W stosunku do przestępstwa opisanego przez Paulusa ${ }^{74}$, stwierdzić trzeba, że czynność sprawcza polega na zaaplikowaniu (podaniu) kobiecie środków poronnych. Co ciekawe, w stosunku do zasadniczej regulacji trucicielstwa w lex Cornelia de sicariis et veneficis jest to daleko idąca różnica, ta bowiem - zapewne już od powstania - penalizowała sporządzanie (facere), sprzedawanie (vendere), kupienie (emere), posiadanie (habere) i wreszcie podanie (dare) trucizny ${ }^{75}$. W tym kontekście należy przyjąć, że omawiane przestępstwo stanowi przykład twórczej działalności klasycznej jurysprudencji, uzupełniającej normy zawarte w ustawie Sulli, zbliżony do wypracowanych przez prudentes zasad odpowiedzialności lekarzy czy znachorów, którzy zaordynowaliby pacjentowi substancję, która zamiast lekiem, okazałaby się trucizną ${ }^{76}$. Brak jest natomiast wystarczających podstaw źródłowych, by jednoznacznie stwierdzić, że odpowiedzialności karnej podlegały również osoby sprzedające środki poronne. Byłoby to logiczne, biorąc pod uwagę, że dotyczyła ona również sprzedawców olejków wzmagających potencję (pigmentarii) ${ }^{77}$.

72 Zob. D. 48, 19, 16. Na temat teoretycznego modelu przestępstwa, jaki proponował ten jurysta, zob. G. Sposito, "Quattuor genera... septem modis”: le circostanze del reato in D. 48, 19, 16 (Claudius Starninus „De poenis paganorum”), "Studia et Documenta Historiae et Iuris” 1999, nr 65, s. 114 i nast.; L. Garofalo, Pojęcia i żywotność rzymskiego prawa karnego, „Zeszyty Prawnicze" 2003, z. 1, s. 28 i nast.; W. Mossakowski, Czyn karalny wedtug koncepcji Klaudiusza Saturnina, „Acta Universitatis Wratislaviensis” Prawo 2008, nr 305 (3063), s. 217 i nast.; K. Amielańczyk, Crimina legitima..., s. 88 i nast.

73 Zob. K. Amielańczyk, Crimina legitima..., s. 89.

${ }^{74}$ Zob. D. 48, 19, 38.

75 Zob. K. Amielańczyk, Lex Cornelia..., s. 92. Niemniej jednak zasadne jest stwierdzenie R. Mentxaki, iż jest to szczególny rodzaj odpowiedzialności za trucicielstwo w rozumieniu ustawy Sulli, zob. R. Mentxaka, El aborto..., s. 317.

76 Zob. D. 48, 8, 3, 2. Na ten temat, zob. A. Wacke, Fahrlässige Vergehen im römischen Strafrecht, „Revue Internationale des Droits de l'Antiquité” 1979, t. 26, s. 531-532; G. Redl, Die fahrlässige..., s. 311 i nast.; K. Amielańczyk, Lex Cornelia..., s. 91-92; tenże, Rzymianie i ich "prawo medyczne"..., s. 80-81.

77 Zob. D. 48, 8, 3, 3. 
Przechodząc do zagadnień związanych z wolą sprawczą, dziś określaną jako znamiona strony podmiotowej ${ }^{78}$, stwierdzić należy, że analiza tekstów Marcjanusa i Tryfoninusa wskazuje, iż kobieta mogła dopuścić się przestępstwa jedynie poprzez swoje działanie umyślne. Towarzyszył jej wyraźny zamiar pozbawienia znienawidzonego męża potomstwa (ne iam inimico marito filium procrearet) $)^{79}$. Marcjanus wydaje się akcentować oszukańczy charakter działań żony (maritum liberis fraudasse) ${ }^{80}$. Jurysta wprost stwierdza, że kobieta ciężarna data opera abegit ${ }^{81}$, co wystarczające jest do uznania, że jej działanie musiało nastąpić umyślnie ${ }^{82}$.

Odmiennie przedstawia się zagadnienie znamion strony podmiotowej przestępstwa podania kobiecie środków poronnych. I w tym względzie przypomina ono pozostałe twórcze uzupełnienia ustawy Sulli przez jurysprudencję, bowiem sprawca ponosił odpowiedzialność także wówczas, gdy działał nieumyślnie ${ }^{83}$ - podobnie jak lekarz, ordynujący leki, których przyjęcie przez pacjenta skutkowałoby śmiercią pacjenta ${ }^{84}$. Dla rekonstrukcji znamion strony podmiotowej kluczowym jest użyty przez Paulusa zwrot: ...etsi dolo non faciant, tamen quia mali exempli res est ${ }^{85}$. Warunkiem odpowiedzialności sprawcy nie była zatem intencja uśmiercenia dziecka poczętego, a tym bardziej jego matki. Istotny był jednak skutek, który, z uwagi na jego (choćby) nieumyślne działania, nastąpił. Jeżeli skutkiem tym była śmierć dziecka in utero, wówczas sprawcy groziła kara zesłania do pracy w kopalniach (dla osób gorzej sytuowanych społecznie humiliores) bądź kara wygnania na wyspę połączona z konfiskatą majątku (dla przedstawicieli warstw uprzywilejowanych - honestiores). W sytuacji,

78 Na temat wypracowania w dorobku jurysprudencji zrębów koncepcji winy umyślnej oraz nieumyślnej, zob. L. Garofalo, Pojęcia i żywotność..., s. 23-24; D. 48, 19, 11, 2.

79 Zob. D. 48, 19, 39.

80 Zob. D. 47, 11, 4.

81 Tamże.

82 Zob. K. Amielańczyk, Crimina legitima..., s. 129; A. Wacke, Fahrlässige..., s. 555-556.

83 Andreas Wacke twierdzi jednak, że przestępstwo to można było popełnić jedynie nieumyślnie, bowiem w przypadku działania umyślnego czyn kwalifikował się jako zabójstwo, zob. tenże, Fahrlässige..., s. 533-534.

84 Zob. K. Amielańczyk, Rzymianie i ich "prawo medyczne”. .., s. 80-81.

85 D. 48, 19, 38. Redl wskazuje, że zwrot malo exemplo należy traktować tu w sposób dosłowny - według tej autorki ustawodawca zdecydował się na inkryminację podawania afrodyzjaków i środków poronnych nieumyślnie z uwagi na potrzeby prewencyjne, zob. G. Redl, Die fahrlässige..., s. 318 i nast. 
gdy zmarło zarówno dziecko poczęte, jak i kobieta, karą przewidzianą dla sprawcy była śmierć.

Analiza znamion przestępstwa opisanego przez Paulusa w zestawieniu z czynem objętym reskryptem Septymiusza Sewera i Karakalli prowadzi również do wniosku, że odpowiedzialność osób trzecich mogła mieć charakter zbliżony do obecnego „współsprawstwa” lub „pomocnictwa” przy przestępstwie popełnianym przez matkę, jak również charakter samoistny. Krytycznie należy odnieść się zatem do prezentowanego w literaturze poglądu, że odpowiedzialność na podstawie reskryptu ponosiła nie tylko kobieta, ale również osoby trzecie ${ }^{86}$. Jak bowiem wskazuje K. Amielańczyk, praktyką stosowaną przez rzymskiego prawodawcę było enumeratywne wymienianie rozmaitych kategorii współsprawców ${ }^{87}$. Poza przekazem Paulusa śladów tego rodzaju wyliczenia w zachowanych źródłach nie znajdujemy.

Na zakończenie warto jeszcze odnieść się do tezy S. Longosza, że prawa przewidujące sankcje karne za dokonanie aborcji „szybko poszły $\mathrm{w}$ zapomnienie" ${ }^{88}$. Jest ona mocno dyskusyjna, przynajmniej w zakresie, który dotyczy przestępstwa podania kobiecie środków poronnych przez osobę trzecią. Trzeba bowiem przypomnieć, że przestępstwo to - objęte przez lex Cornelia de sicariis et veneficis - zostało potwierdzone w Sentencjach Paulusa, które na mocy decyzji Konstantyna Wielkiego uzyskały na początku IV w. moc powszechnie obowiązującą ${ }^{89}$. Nie ma zatem podstaw, by twierdzić, że prawo to nie było wówczas stosowane.

Konkludując powyższe rozważania, można sformułować wniosek, że aborcję w prawie rzymskim uznawano za przestępstwo od III w. po Chr. Odpowiedzialność kobiety brzemiennej - oparta o reskrypt Septymiusza Sewera i Karakalli - ograniczona była jedynie do sytuacji, gdy uśmierciła ona swoje nienarodzone dziecko umyślnie i z intencją pozbawienia męża (lub byłego męża) potomstwa. Sankcją karną przewidzianą przez prawodawcę było tymczasowe wygnanie. Odpowiedzialność osób aplikujących kobiecie ciężarnej środki poronne opierała się natomiast na lex Cornelia de

86 Zob. R. Mentxaka, El aborto..., s. 313 wraz z przytoczoną przez autorkę literaturą.

87 Zob. K. Amielańczyk, Crimina legitima..., s. 153.

88 S. Longosz, Prawo rzymskie..., s. 218.

89 Zob. Codex Theodosianus, [w:] T. Mommsen, P. Meyer (red.), Theodosiani libri XVI cum Constitutionibus Sirmondianis et Leges Novellae ad Theodosianum Pertinentes, Berolini 1905, 1, 4, 2. Zob. również J. Gaudemet, La formation du droit séculier et du droit de l'Église aux IV et $V^{\mathrm{e}}$ siècles, Sirey 1957, s. 73. 
sicariis et veneficis, bowiem przestępstwo to stanowiło, datowane na okres klasyczny, uzupełnienie tej ustawy poprzez jej twórczą interpretację dokonaną przez jurysprudencję. Był to czyn odrębny od przestępstwa kobiety, który popełnić można było również nieumyślnie.

Słowa kluczowe: aborcja, prawo rzymskie, nasciturus

\section{Bibliografia}

Accursius, Digestum Novum seu Pandectarum Iuris Civilis, t. 3, Lugduni 1627.

Albanese B., Note sull'evoluzione storica del ius vitae ac necis, [w:] G.G. Archi (red.), Scritti in onore di Contardo Ferrini pubblicati in occasione della sua beatificazione, t. 3, Milano 1948, s. 343-366.

Amielańczyk K., Crimina legitima w rzymskim prawie publicznym, Lublin 2013.

Amielańczyk K., Lex Cornelia de sicariis et veneficis. Ustawa Korneliusza Sulli przeciwko nożownikom i trucicielom. 81 r. p.n.e., Lublin 2011.

Amielańczyk K., Rzymianie i ich „prawo medyczne” (aspekty prawno-karne), „Zeszyty Prawnicze" 2011, t. 11, z. 1, s. 69-90.

Amielańczyk K., Rzymskie prawo karne w reskryptach cesarza Hadriana, Lublin 2006.

Amielańczyk K., Zmierzch "ius vitae necisque” (z badań nad prawodawstwem karnym cesarza Hadriana), „Annales Universitatis Mariae Curie-Skłodowska” Sectio G Ius 2007/2008, t. 54/55, s. 7-24.

Balducci A., Intorno al iudicium domesticum, „Archivio Giuridico" 1976, t. 191, nr 1/2, s. 69-97.

Berger A., Partus abactus, [w:] A. Berger, Encyclopedic Dictionary of Roman Law, Philadelphia 1953, s. 619.

Bernard Ch., E. Deleury, F. Dion, P. Gaudette, Le statut de l'embryon humain dans l'Antiquité gréco-romaine, „Laval Théologique et Philosophique” 1989, t. 45, nr 2, s. 179-195.

Biondi B., Il diritto romano cristiano, t. 2, Milano 1952.

Bonfante P., Corso di diritto romano, t. 1. Diritto di famiglia, Roma 1925.

Bujuklić Z., Leges regiae: pro et contra, „Revue Internationale des Droits de l'Antiquité" 1998, nr 45, s. 89-142.

Bundun-Kulik M., Komentarz do art. 152, [w:] M. Mozgawa (red.), Kodeks karny. Komentarz aktualizowany, LEX 2017.

Burdese A., Manuale di diritto privato romano, Torino 1964.

Ciuła D., Najstarsze przyczyny rozwodu w prawie rzymskim, [w:] A. Dębiński, M. Wójcik (red.), Wokót problematyki małżeństwa w prawie rzymskim. Henrico Insadowski (1888-1946) in memoriam, Lublin 2007, s. 53-71. 
Costa E., Crimini e pene da Romolo a Giustiniano, Bologna 1921.

Crahay R., Les moralistes anciens et l'avortement, "L'Antiquité Classique” 1941, t. 10, z. 1, s. 9-23.

Czebotar Ł., Z. Gądzik, Prawnokarna ochrona życia i zdrowia dziecka poczętego w ustawodawstwie polskim, „Kościół i Prawo” 2013, nr 2 (15), s. 243-270.

Dajczak W., T. Giaro, F. Longchamps de Bérier, Prawo rzymskie. U podstaw prawa prywatnego, Warszawa 2011.

Decimus Iunius Iuvenalis, Satirae cum commentariis, C.F. Heinrich (red.), Bonnae 1839.

Dölger F.J., Das Lebensrecht des ungeborenen Kindes und die Fruchtabtreibung in der Bewertung der heidnischen und christlichen Antike, "Antike und Christentum" 1934 , t. 4, z. 1, s. 1-61.

Eyben E., Family Planning in Graeco-Roman Antiquity, "Ancient Society” 1980/1981, t. $11 / 12$, s. 5-82.

Falchi G.F., Diritto penale romano, Padova 1932.

Fausset W.Y. (red.), M. Tulli Ciceronis pro A. Cluentio oratio with explanatory and critical notes, London 1887.

Ferretti P., In rerum natura esse in rerum humanis nondum esse. L'identità del concepito nel pensiero giurisprudenziale classico, [Milano] 2008.

Franciosi G., Leges regiae, Napoli 2003.

Garofalo L., Pojęcia i żywotność rzymskiego prawa karnego, "Zeszyty Prawnicze” 2003, z. 1, s. 7-41.

Gaudemet J., La formation du droit séculier et du droit de l'Église aux IV et Ve siècles, Sirey 1957.

Giaro T. [w:] W. Dajczak, T. Giaro, F. Longchamps de Bérier, Prawo rzymskie. U podstaw prawa prywatnego, Warszawa 2011, s. 176-199.

Gronovius J., Dissertatio juridica inauguralis ad quatuor fragmenta, quae ex Aelii Marciani primo Regularum libro in Pandectis supersunt, [w:] D. Fellenberg (red.), Jurisprudentia antiqua continens opuscula et dissertationes quibus leges antiquae praesertim Mosaicae, Graecae et Romanae illustrantur, t. 2, Bernae 1761, s. 625-675.

Guarino A., Diritto privato romano. Lezioni istituzionali di diritto romano, Napoli 1958.

Jolowicz H.F., Historical Introduction to the Study of Roman Law, Cambridge 1952.

Jońca M., Aborcja w prawie Rzymu i wczesnego średniowiecza, „Edukacja Prawnicza” 2012, nr 10 (136), s. 46-47.

Jońca M., Parricidium w prawie rzymskim, Lublin 2008.

Jońca M., Subiectum iuris, [w:] A. Dębiński, M. Jońca (red.), Leksykon tradycji rzymskiego prawa prywatnego. Podstawowe pojęcia, Warszawa 2016, s. 354-355.

Kaser M., Der Inhalt der patria potestas, „Zeitschrift der Savigny-Stiftung für Rechtsgeschichte. Romanistische Abteilung" 1938, t. 58, s. 62-87.

Kaser M., Das römische Privatrecht, t. 1, München 1971. 
Kaser M., Das römische Privatrecht, t. 2, München 1975.

Królikowski M., Komentarz do art. 152, [w:] M. Królikowski, R. Zawłocki (red.), Kodeks karny. Część szczególna, t. 1. Komentarz do art. 117-221, Warszawa 2017, Legalis.

Krueger P., T. Mommsen, R. Schoell (red.), Corpus Iuris Civilis, t. 1/3, Berolini 1893-1895.

Księżopolska-Breś A., Odpowiedzialność karna za dzieciobójstwo w prawie polskim, Warszawa 2010.

Kuebler B., E. Seckel (red.), Gai Institutionum Commentarii Quattuor, Lipsiae 1903.

Kunkel W., Das Konsilium im Hausgericht, "Zeitschrift der Savigny-Stiftung für Rechtsgeschichte. Romanistische Abteilung" 1966, t. 83, s. 219-151.

Kuryłowicz M., Prawo rzymskie. Historia, tradycja, współczesność, Lublin 2003.

Laurendi R., Leges regiae. «Ioui sacer esto» nelle leges Numae: nuova esegesi di Festo s.v. Aliuta, [w:] G. Purpura (red.), Revisione ed integrazione dei Fontes Iuris Romani Anteiustiniani ( FIRA). Studi preparatori, t. 1. Leges, Torino 2012, s. 13-39.

Litewski W., Abortio, [w:] W. Litewski, Stownik encyklopedyczny prawa rzymskiego, Kraków 1998, s. 3.

Litewski W., Rzymski proces karny, Kraków 2003.

Longosz S., Prawo rzymskie wobec aborcji, [w:] H. Kowalski, M. Kuryłowicz (red.), Contra leges et bonos mores. Przestepstwa obyczajowe w starożytnej Grecji i Rzymie, Lublin 2005, s. 209-220.

Łapicki B., Ustawy królewskie w starożytnym Rzymie. Zagadnienie ich autentyczności, „Pamiętnik Historyczno-Prawny” 1933, t. 12, z. 6, s. 303-332 (wydane w formie odrębnej broszury).

Łapicki B., Władza ojcowska w starożytnym Rzymie. Okres klasyczny, seria: Bibliotheca Universitatis Liberae Polonae, nr 5 (28), Warszawa 1937.

Marencus J.B., Joannes Bartholomæus Marencus j.u.d. civis Braydensis ut in amplissimum j.c. collegium cooptetur in regio Taurinensi athenaeo, Taurini 1787.

Marcus Tullius Cicero, Pro A. Cluentio oratio, [w:] W.Y. Fausset (red.), M. Tulli Ciceronis pro A. Cluentio oratio with explanatory and critical notes, London 1887.

Mentxaka R., El aborto en el derecho romano. Consideraciones sobre las fuentes juridicas clásicas, „Estudios de Deusto” 1983, t. 31, nr 61, s. 307-319.

Mommsen T., P. Meyer (red.), Theodosiani libri XVI cum Constitutionibus Sirmondianis et Leges Novellae ad Theodosianum Pertinentes, Berolini 1905.

Morin M., Les confins du droit civil et du droit pénal: l'avortement et les droits de l'enfant conçu, „McGill Law Journal” 1997, t. 42, nr 2, s. 199-280.

Mossakowski W., Czyn karalny wedtug koncepcji Klaudiusza Saturnina, "Acta Universitatis Wratislaviensis" Prawo 2008, nr 305 (3063), s. 217-229.

Mossakowski W., Iudicium domesticum w okresie republiki rzymskiej, [w:] J. Jundziłł (red.), Rodzina w społeczeństwach antycznych i wczesnym chrześcijaństwie. Literatura, prawo, epigrafika, sztuka, Bydgoszcz 1995, s. 85-95. 
Mueller L. (red.), P. Ovidii Asonis Carmina Amatoria, Berolini 1861.

Muyart de Vouglans P.F., Les loix criminelles de France, dans leur ordre naturel, t. 1, Paris 1781.

Nardi E., Procurato aborto in mondo greco-romano, Milano 1971.

Niczyporuk P., Prywatnoprawna ochrona dziecka poczętego w prawie rzymskim, Białystok 2009.

Niczyporuk P., Stwierdzenie ciąży (inspectio ventris) jako środek ochrony interesów dziecka poczętego w prawie rzymskim, "Miscellanea Historico-Iuridica” 2010, t. 9, s. 29-40.

Olszówka M., Początek człowieka a początek życia ludzkiego w orzecznictwie Trybunału Konstytucyjnego i Sądu Najwyższego, [w:] L. Bosek, M. Królikowski (red.), Wspótczesne wyzwania bioetyczne, Warszawa 2010, s. 199-219.

Osuchowski W., Zarys rzymskiego prawa prywatnego, Warszawa 1962.

Pankiewicz R., Tzw. leges regiae a problematyka rodziny rzymskiej w epoce archaicznej, [w:] J. Jundziłł (red.), Rodzina w społeczeństwach antycznych i wczesnym chrześcijaństwie. Literatura, prawo, epigrafika, sztuka, Bydgoszcz 1995, s. 59-84.

Pauli Sententiae, [w:] G. Baviera (red.), Fontes Iuris Romani Anteiustiniani, t. 2, Firenze 1968.

Petit C., What Does Pseudo-Galen Tell us That Galen Does Not? Ancient Medical Schools in the Roman Empire, [w:] P. Adamson, R. Hansberger, J. Wilberding (red.), Philosophical Themes in Galen, London 2014, s. 269-290.

Pikuła Ł., Nasciturus, [w:] A. Dębiński, M. Jońca (red.), Leksykon tradycji rzymskiego prawa prywatnego. Podstawowe pojeccia, Warszawa 2016, s. 244.

Plaza y Moraza P., Epitomes delictorum, causarumque criminalium, ex iure ponticio, regio, et caesareo, t. 1, Lugduni 1560.

Plebanek E., Życie i zdrowie dziecka poczetego jako przedmiot prawnokarnej ochrony (wybrane problemy wykładnicze w perspektywie najnowszych propozycji legislacyjnych), „Czasopismo Prawa Karnego i Nauk Penalnych” 2016, t. 20, z. 4, s. 7-34.

Potulski J., Dziecko poczęte jako pokrzywdzony w przestępstwie aborcyjnym. Postanowienie SN z dnia 26 marca 2009 r., I KZP 2/09, „Gdańskie Studia Prawnicze Przegląd Orzecznictwa” 2009, nr 4, s. 131-138.

Rafałowicz P., Początek ochrony życia dziecka poczętego - analiza przedmiotu ochrony przestepstw aborcyjnych, „Pomeranian Journal of Life Sciences” 2016, t. 62, nr 3, s. 62-66.

Ramon A., Repressione domestica e persecuzione cittadina degli illeciti commessi da donne e "filii familias", [w:] L. Garofalo (red.), Il giudice privato nel processo civile romano. Omaggio ad Alberto Burdese, t. 3, Padova 2015, s. 617-678.

Redl G., Die fahrlässige Tötung durch Verabreichung schädigender Substanzen im römischen Strafrecht der Prinzipatszeit, „Revue Internationale des Droits de l'Antiquité" 2005, t. 52, s. 309-324.

Rominkiewicz J., Czy w prawie ateńskim istniat zakaz aborcji, "Acta Universitatis Wratislaviensis" Prawo 2012, nr 314, s. 17-40. 
Ruggiero A., Nuove riflessioni in tema di tribunale domestico, [w:] V. Giuffrè (red.), Sodalitas. Scritti in onore di Antonio Guarino, t. 4, Napoli 1984, s. 1593-1600.

Salerno F., "Ad metalla”. Aspetti giuridici del lavoro in miniera, Napoli 2003.

Sanna M.V., Spes nascendi - spes patris, "Annali del Seminario Giuridico dell'Università degli Studi di Palermo" 2012, t. 55, s. 519-552.

Santalucia B., Osservazioni sulla repressione criminale romana in età regia, [w:] M. Torelli i in. (red.), Le délit religieux dans la cité antique. Actes de la table ronde de Rome (6-7 avril 1978), Rome 1981, s. 39-49.

Sevilla Conde A., Morir ante suum diem. La infancia en Roma a través de la muerte, [w:] D. Justel Vicente (red.), Niños en la Antigüedad. Estudios sobre la infancia en el Mediterráneo antiguo, Zaragoza 2012, s. 199-233.

Sposito G., "Quattuor genera... septem modis": le circostanze del reato in D. 48, 19, 16 (Claudius Saturnius „De poenis paganorum"), "Studia et Documenta Historiae et Iuris” 1999, nr 65, s. 95-116.

Starowieyski M., Aborcja $i$ życie nienarodzonych w starożytności chrześcijańskiej, „Warszawskie Studia Teologiczne” 2009, t. 22, cz. 1, s. 117-147.

Tarwacka A., "Leges regiae”, "Zeszyty Prawnicze” 2004, t. 4, z. 1, s. 233-260.

Taubenschlag R., Rzymskie prawo prywatne, Warszawa 1955.

Tertulian, Apologeticum, C. Becker (red.), Munich 1962.

Tollozan P., Dissertatio philologico-iuridica inauguralis de maleficis et mathematicis et caeteris similibus, [w:] G. Oelrichs (red.), Theasuri dissertationum iuridicarum selectissimarum in Academiis Belgicis habitarum, vol. 1, t. 3, Bremae-Lipsiae 1768, s. 213-276.

Voci P., Istituzioni di diritto Romano, Milano 1954.

Volterra E., Il preteso tribunale domestico in diritto romano, "Rivista Italiana per le Scienze Giuridiche" 1948, t. 2, z. 1/4, s. 104-153.

Volterra E., Istituzioni di diritto privato romano, Roma 1961.

Wacke A., Fahrlässige Vergehen im römischen Strafrecht, „Revue Internationale des Droits de l'Antiquité" 1979, t. 26, s. 506-566.

Waldstein W., Problem interpretacji źródeł a status dziecka w łonie kobiety (nasciturus), tłum. F. Wycisk, "Zeszyty Prawnicze” 2006, t. 6, z. 2, s. 7-32.

Watson A., Roman Private Law and the Leges Regiae, "Journal of Roman Studies" 1972 , t. 62 , s. $100-105$.

Watts W.J., Ovid, the Law and Roman Society on Abortion, "Acta Classica” 1973, t. 16, nr 1, s. 89-101.

K. Wiak, Komentarz do art. 152, [w:] A. Grześkowiak, K. Wiak (red.), Kodeks karny. Komentarz, Warszawa 2018, Legalis.

Wiak K., Polskie prawo karne wobec dziecka poczętego, [w:] A. Dębiński, A. Grześkowiak, K. Wiak (red.), Ius et lex. Księga Jubileuszowa ku czci Profesora Adama Strzembosza, Lublin 2002, s. 101-116. 
Wibier M., Cicero's Reception in the Juristic Tradition of the Early Empire, [w:] P.J. du Plesssis (red.), Cicero's Law: Rethinking Roman Law of the Late Republic, Edinburgh 2016, s. 100-122.

Zabłocki J., Si mulier vinum bibit condemnatur, „Prawo Kanoniczne” 1989, t. 32, nr 1/2, s. 223-232.

Zeigler K. (red.), Plutarchi Vitae Parallelae, t. 1, fasc. 1, Leipzig 1957.

Zoz M.G., Le costituzioni imperiali nella giurisprudenza. Fonti giuridiche e diritto delle persone, Trieste 2007.

\section{CRIMEN ABORTIONIS IN ROMAN CRIMINAL LAW}

\section{Sum mary}

The subject of considerations taken in this paper is the issue of criminalization of abortion in Roman law. For centuries, abortion - although occasionally criticized by pagan writers - was not considered a crime by the Romans. Situation changed in the third century, when Spetymius Severus and Karakalla issued a rescript, according to which a divorced woman committing an abortion without the consent of her ex-husband should be condemned to exile. A separate sanction implemented on the basis of lex Cornelia de sicariis et veneficis was prescribed for perpetrators who gave specifics causing abortion to a woman. The purpose of the article is to try to establish the relationship between these crimes by identifying their names.

Key words: abortion, Roman law, nasciturus

\section{ПРЕСТУПЛЕНИЕ АБОРТА В РИМСКОМ УГОЛОВНОМ ПРАВЕ}

\section{Резюме}

Предметом обсуждения в статье является вопрос о наказании за аборт в римском праве. На протяжении веков аборт - хотя иногда и подвергался критике со стороны языческих писателей - не был криминализирован римлянами. Это изменилось только в третьем веке, когда Септимий Север и Каракалла выпустили рескрипт, согласно которому разведенная женщина, которая делает аборт без согласия своего бывшего мужа, должна быть приговорена к изгнанию. Отдельные санкции, введенные на основе lex Cornelia de sicariis et veneficis, были наложены на лиц, делавших аборт женщинам. Целью статьи является попытка установить связь между этими преступлениями путем идентификации их признаков.

Ключевые слова: аборт, римское право, nasciturus 